\title{
$\mathrm{Al} / \mathrm{Ni}$ 混合粉末の半溶融加工で作製した金属間化合物とその高温強度特性
}

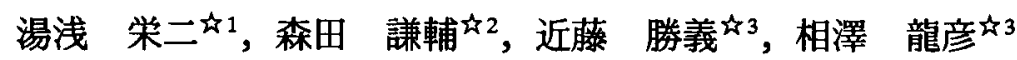 \\ 41 武蔵工業大学工学部機械工学科, 个 158-8557 世田谷区玉堤 1-28-1. \\ 42 武藏工業大学大学院, $\overline{1} 158-8557$ 世田谷区玉堤 1-28-1. \\ 中 3 東京大学先端科学技術研究センター, ₹ 153-8904 目黒区駒場 4-6-1.
}

\section{Intermetallic Compound Produced by Semi-Solid Processing from Al/Ni Powder Mixture and its Mechanical Strength at Elevated Temperature}

\author{
Eiji Yuasa ${ }^{\text {मै1 } 1}$, Kensuke Morita ${ }^{42}$, Katsuyoshi Kondoh ${ }^{\text {मै } 3}$ and Tatsuhiko Aizawa ${ }^{\text {th } 3}$ \\ म1 1 Dept. Mech., Fac. Eng., Musashi Institute of Technology, 1-28-1 Tamazutsumi Setagaya-ku, Tokyo 158-8557. \\ ${ }^{2}{ }^{2}$ Graduate School, Musashi Institute of Technology, 1-28-1 Tamazutsumi Setagaya-ku, Tokyo 158-8557. \\ ${ }^{3}$ Reseach Center for Advanced Science and Technology, The University of Tokyo, 4-6-1 Komaba Meguro-ku, Tokyo 158-8904.
}

Received July 22, 2002

\section{SYNOPSIS}

To produce Al-Ni intermetallic compound, $\mathrm{Al}-42$ mass\% $\%$ i powder mixture was formed by back-forward extrusion at the temperature near to melting point of aluminum. The structure of alloy extruded at $910 \mathrm{~K}$ consists of $\mathrm{Al}_{3} \mathrm{Ni}$, $\mathrm{Al}_{3} \mathrm{Ni}_{2}$ and eutectic structure. In the alloy extruded at $1010 \mathrm{~K}$, it consists of the intermetallic compound $\mathrm{Al}_{3} \mathrm{Ni}$ and $\mathrm{Al}_{3} \mathrm{Ni}_{2}$. The volume fraction of each phase in the structure changes by the heat treatment, that is, the $\mathrm{Al}_{3} \mathrm{Ni}$ phase increases with increase of heat-treating temperature and the eutectic structure disappears. High temperature deformation behaviors of these alloys were characterized by compressive test at various temperatures. The alloy of intermetallic compound containing the eutectic structure have large ductility, the eutectic structure transforms to $\mathrm{Al}_{3} \mathrm{Ni}$ phase during the high temperature deformation and this transformation similarly occurs by the heat treatment at eutectic temperature. It was recognized that the compressive yield stresses in $\mathrm{Al}_{3} \mathrm{Ni}_{\text {and }} \mathrm{Al}_{3} \mathrm{Ni}_{2}$ phases became higher with rising deformation temperature, it is referred to as "anomalous strengthening behavior of intermetallic compound". KEY WORDS

intermetallic compound, Al-Ni alloy, semi-solid processing, high-temperature deformation, mechanical strength

\section{1 緒言}

一般に，金属間化合物は耐熱構造材料として期待でき， 種々の方法での製造が試みられ，その高温強度特性が調べら れている．しかし金属間化合物は，高溶融温度，高温高強度 であるがゆえに，溶解・鋳造法や熱間加工では製造・成形か 困難である.

粉末治金法 1 ,2)であれば，製造も容易で，得られる合金の結 晶粒も微細である。そして, NiAlのように³), 673Kにおいて もHall-Petchの式が成り立つので，微細結晶粒の金属間化合物 は高温強度に優れる. また, $\mathrm{Al}-\mathrm{Ni}$ 系合金の場合, 自己燃焼法 (SHS)等を用いれば，比較的低エネルキー消費量で製造可能で あり， $\mathrm{Ni}_{3} \mathrm{Al}^{4}$ ) や $\mathrm{AlNi}^{\mathrm{s})}$ 合金などが作られ，その高温強度特性 が調べられている. 半溶融・半凝固加工 (Semi-Solid Metal Processing)のは金属の固液共存状態で加工する方法で, 粗大な 鋳造組織が生成することなく, 低成形力で加工でき, 近年, 半
溶融・半㠜固加工用の実用成形機も開発されている》。出発材 料が融点の異なる混合粉末であれば, 低融点側金属の融解に よって液相が生成し, 固液共存状態のスラリーとなる。特に， Al-Ni 混合粉末では, SHS 法のように, 固相反応過程で発熱かs 生じるため, 比較的低温でスラリーが生成し，固相一液相間 の反応も急速に進行して，加熱・凝固の過程で金属間化合物 が生成する. 前報ではす， Al- $\mathrm{Ni}$ 混合粉末の半溶融加工法を利 用して, Al-Ni湿合粉末から金属間化合物を製造・成形するた めに，等速加熱過程で生じるスラリーと凝固後に金属間化合 物の生成について明らかにし，半溶融加エで成形が可能であ ることを示した.そこで, 本研究では, Al-42 mass\% Ni 混合粉 末を $\mathrm{Al}$ の融点温度近傍での半溶融押出し加エによって Al-Ni 合金を創製し，耐熱Al合金として期待されているAl側の金属 間化合物である $\mathrm{Al}_{3} \mathrm{Ni}$ 相が主要組織となる $\mathrm{Al}-\mathrm{Ni}$ 合金について 常温及び高温での強度特性を検討した。 


\section{2 実験方法}

出発材料は噴蓩 $\mathrm{Al}$ 粉末(平均粒径 $146 \mu \mathrm{m}$, 純度 $99.8 \%$ ) と還 元 $\mathrm{Ni}$ 粉末 (純度 $99.8 \%$ ) とし, Al-42 mass\% Ni 配合した. $\mathrm{Ni}$ 粉 末は $5 \sim 105 \mu \mathrm{m}, 5 \sim 53 \mu \mathrm{m}, 53 \sim 105 \mu \mathrm{m}$ の 3 種類の粒径に 篩分けして使用した.混合粉末を直径 $26 \mathrm{~mm}$, 高さ $43 \sim 46 \mathrm{~mm}$, 相対密度 80〜90\%の予備圧粉体をビレットとし，これをコン テナ内のステンレス鋼管中に入れ，平均昇温速度 $0.2 \mathrm{~K} / \mathrm{s}$ で， 種々のコンテナ温度まで加熱した. 加熱中のコンテナ温度と 圧粉体内部温度の関係をあらかじめ調べて, コンテナ温度を 制御して成形温度を定めた. 成形温度が所定の温度に達した 時点で, 直ちに内径 $13 \mathrm{~mm}$ (押出し比 4.0 )のポンチを押込み速度 $3.5 \times 10^{-3} \mathrm{~m} / \mathrm{s}$ で挿入し, 後方押出し形式の成形を行った. 得られ た成形体について, 押出し方向断面の各部の光顕組織, $\mathbf{X}$ 線回 折, EPMA 分析して, 生成相の確認, およびそれらの存在量 を画像処理により体積率として求めた. 高温変形挙動は種々 の温度での圧縮試験より調べた. 押出し成形体より $\phi 10 \mathrm{~mm} \times$ $15 \mathrm{~mm}$ の試験片を作製し,アルゴンガス需囲気中の電気炉内で 圧縮試験した．試験速度はクロスヘッドの移動速度で $0.17 \mathrm{~mm} / \mathrm{s}$ とした. 超硬合金製圧縮板と試験片間には二硫化モリブデン 系の潤滑剂を塗布した。また, 試験後の試験片の組織観察も 行った。

\section{3 実験結果およひ考察}

3.1 半溶融状態での押出し成形

成形温度を定めるために，コンテナ加熱温度と圧粉体ビ レット中の温度上昇の関係を調へた. Fig.1 は, $5 \sim 105 \mu \mathrm{m}$ の $\mathrm{Ni}$ 粒径, 予備圧粉密度 $80 \%$ のビレットを用いた時の結果を示 す. 約 $0.2 \mathrm{~K} / \mathrm{s}$ の等速加熱により圧粉体ビレット中の温度は上 昇し, コンテナ温度が $850 \mathrm{~K}$ に達した時, ビレット中の温度は コンテナ温度以上となり, 圧粉体中で固相反応が生じ，発熱 することを示唆した．そして $\mathrm{Al}$ の溶融温度に達すると $\mathrm{Al}-\mathrm{Ni}$

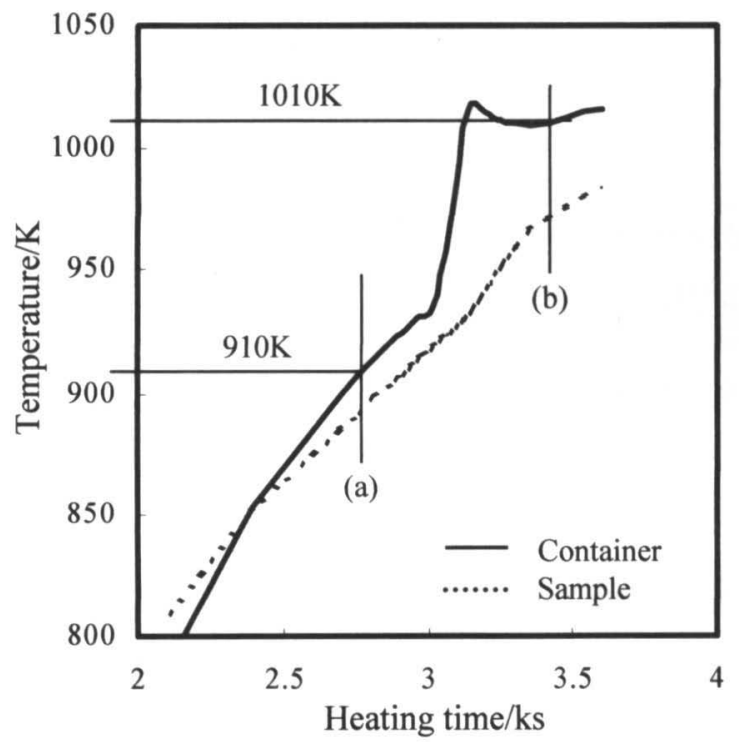

Fig.1 Change of temperature in powder compact with increase of container temperature.
間で燃焼合成 ${ }^{3)}$ による発熱反応し，ビレット内は著しく温度 上昇して $1000 \mathrm{~K}$ 以上になる．この段階では $\mathrm{Al}-\mathrm{Ni}$ 合金の液相 が生成している.これらの発熱温度は $\mathrm{Ni}$ 粒径や予備圧粉体密 度によって異なると考えられる．そこで本実験条件の範囲内 で, いずれも (a)固相反応して温度上昇するが, Alの融点まで 達していない $910 \mathrm{~K}$ (コンテナ温度 $898 \mathrm{~K}$ ) と (b) Al が溶融して 液相が生成し, 著しく温度上昇した $1010 \mathrm{~K}$ (973 K) を成形温度 とした.

いずれの条件においても約 $80 \mathrm{~mm}$ の長さの成形体が得られ るが, その先端部 8〜 10mmのところは成形圧力不足のため, 粒子間空洞と発生ガスが封じ込められ空洞が存在し,また $910 \mathrm{~K}$ 成形ではダイス流入部に $\mathrm{Al}$ と $\mathrm{Ni}$ が未反応のまま粒子状と なって残存するところが観察された.そこで,成形体は両端部 を取り除き試験片として用いた．Fig.2 は $5 \sim 105 \mu \mathrm{m}$ の Ni 粒 径, 予備圧粉密度 $80 \%$ のビレットについて, 成形温度 $910 \mathrm{~K}$ と $1010 \mathrm{~K} て ゙$ 押出した成形体の中央部における押出し方向断面 の光顕組織を示す. $910 \mathrm{~K}$ 成形体では $\mathrm{Al}_{3} \mathrm{Ni}_{2}$ 相を芯とし, これ を包囲する $\mathrm{Al}_{3} \mathrm{Ni}$ 相が生成している. また未反応の $\mathrm{Ni}$ 相が芯 となって残留する粒子や $\mathrm{Al}_{3} \mathrm{Ni}$ 相間には僅かに共晶組織も見ら れた. $1010 \mathrm{~K}$ 成形体では, 塊状に発達した $\mathrm{Al}_{3} \mathrm{Ni}$ 相と共晶組織 から構成している.

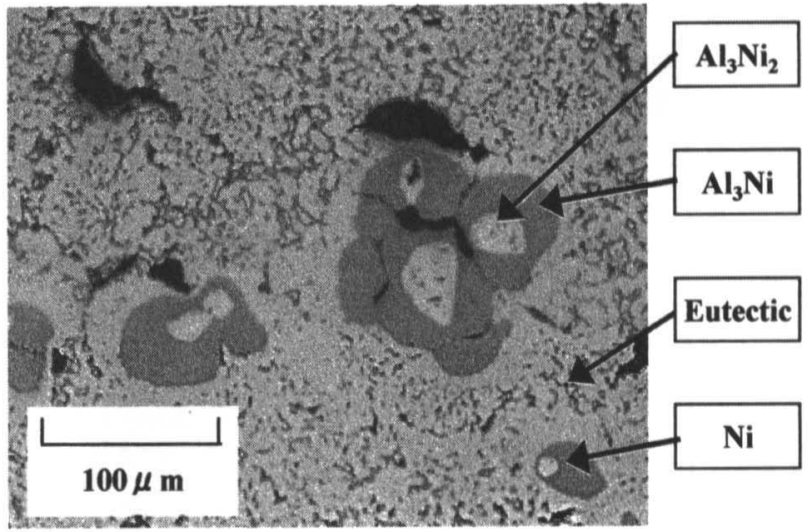

(a) $910 \mathrm{~K}$ (Container 898K)

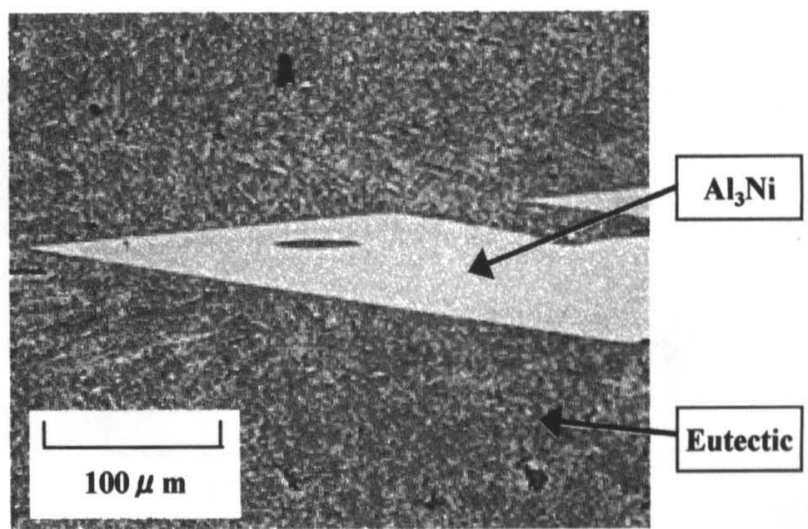

(b) $1010 \mathrm{~K}$ (Container 973K)

Fig.2 Optical micrographs of alloys extruded at $910 \mathrm{~K}$ and $1010 \mathrm{~K}$. 
前報§で確認したように，Al/Ni混合粉末を等速加熱すると， $\mathrm{Al}-\mathrm{Ni}$ 間で固相反応し, 共晶組成となって, $\mathrm{Al}$ の溶融温度以 下でも液相が生成する。一旦，液相が生成すると反応が急速 に進行して，中心部が $\mathrm{Al}_{3} \mathrm{Ni}_{2}$ 相，その周囲に $\mathrm{Al}_{3} \mathrm{Ni}$ 相が生成す る. 液相は成形中および成形後の凝固過程で $\alpha-\mathrm{Al}$ と $\mathrm{Al}_{3} \mathrm{Ni}$ の 共晶組織となる．1010Kでの成形体では，固一液相共存状態 で押出しするため, 固相は $\mathrm{Al}_{3} \mathrm{Ni}$ 相となって成長し, 液相から は共晶組織が形成する.910 Kの成形体には未反応のまま残存 した $\mathrm{Ni}$ 粒子が存在したが，このような $\mathrm{Ni}$ 粒子は配合時の $\mathrm{Ni}$ 粒径と予備压粉体密度が影響すると考えられる. Mg-Si 混合 粉末の固相反応において確認されたように9, 固相反応は予備 圧粉過程で粒子表面の酸化被膜が崩壊し，金属接触する新生 面間で反応するため, 高予備圧粉体密度, 小Ni粒径ほど新生 面の接触面積が高く，低温度で固相反応が進行する.そこで

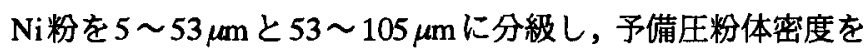
$80,85,90 \%$ として，同様な押出し成形して，成形後の組織観 察を行った. Fig.3(a)と(b)は配合時のNi粒径を分級すること により，それそれ 910Kおよび 1010K成形体に生成する各相 の体積率に及ほすNi粒径の影響について比較して示す.910K 成形体では， Ni 粒径が大きいと末反応 $\mathrm{Ni}$ と共晶組織が増し， $\mathrm{Al}_{3} \mathrm{Ni}_{2}$ 相と $\mathrm{Al}_{3} \mathrm{Ni}$ 相の生成量は減少した. $1010 \mathrm{~K}$ 成形体では未

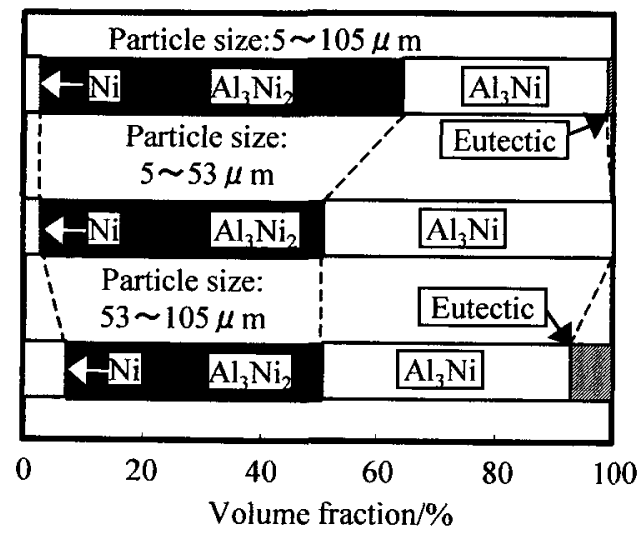

(a) Extrusion at $910 \mathrm{~K}$

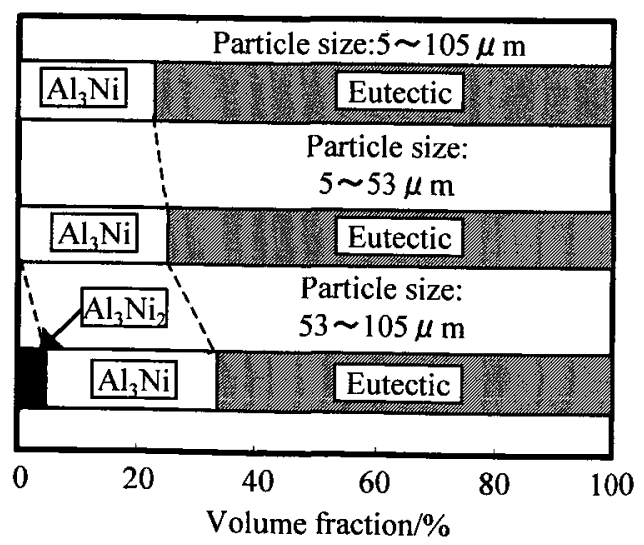

(b) Extrusion at $1010 \mathrm{~K}$

Fig.3 Influence of starting Ni particle size on volume fraction of each phase for alloys extruded at $910 \mathrm{~K}$ and $1010 \mathrm{~K}$.
反応の $\mathrm{Ni}$ はほとんど存在せず， $\mathrm{Ni}$ 粒径が大きいと $\mathrm{Al}_{3} \mathrm{Ni}_{2}$ 相の

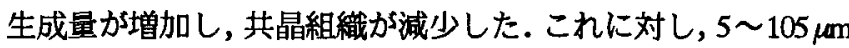
の Ni 粓径について，予備圧粉体密度を $80 \%$ から 90\% まで変 化させたが,いずれの予備圧粉体密度の場合も, $910 \mathrm{~K}$ 成形体 では末反応 $\mathrm{Ni} か ゙ 2 \%$ 程度存在し， $\mathrm{Al}_{3} \mathrm{Ni}_{2}$ 相と $\mathrm{Al}_{3} \mathrm{Ni}$ 相が約 $6: 4$ の割合で生成した. $1010 \mathrm{~K}$ 成形体では $\mathrm{Al}_{3} \mathrm{Ni}$ 相と共晶組織の

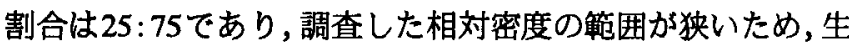
成相の体積率に及ぼす予備圧粉体密度の影響は明暸に現れて いない.

\section{2 高温変形挙動}

$\mathrm{Ni}$ 粒径が 5〜 105 $\mu \mathrm{m}$ の粉末を用い，予備圧粉体密度 80\%の ビレットを半溶融押出し加工して作製した各成形体について 室温および573〜1073Kで圧縮試験した．Fig.4は $910 \mathrm{~K}$ 成形 体について，種々の温度における応力ーひずみ線図を示す． 室温 $(300 \mathrm{~K})$ と $873 \mathrm{~K}$ ではほとんど延性は示さず, $225 \mathrm{MPa}$ お

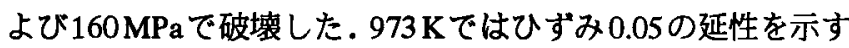

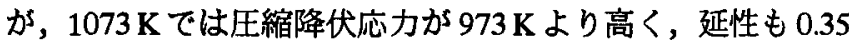
以上のひずみとなる.この成形体の組織は $\mathrm{Al}_{3} \mathrm{Ni}_{2}$ と $\mathrm{Al}_{3} \mathrm{Ni}$ 相か 6:4の割合で構成しているが，共晶組織が $1 \sim 3 \%$ 存在した.

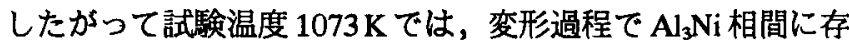
在する共晶組織の融解をともない大きな延性を示したものと 思われる。

Fig.5に1010K成形体の種々の温度における応力ーひずみ線 図を示す.試験温度が上昇するにしたがって降伏応力は低下

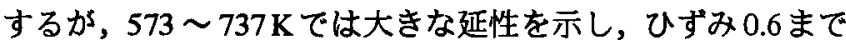

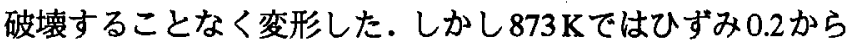
応力が上昇する.この成形体は $\mathrm{Al}_{3} \mathrm{Ni}_{2}$ 相と共晶組織で構成さ れ，その割合は 25:75であった.したがって 573〜 737Kでの 王縮変形は共晶組織が延性に大きく寄与すると思われるが，

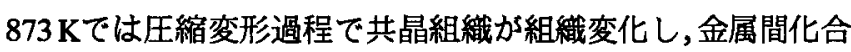
物となるため変形応力が増加したものと考えられる。そこで

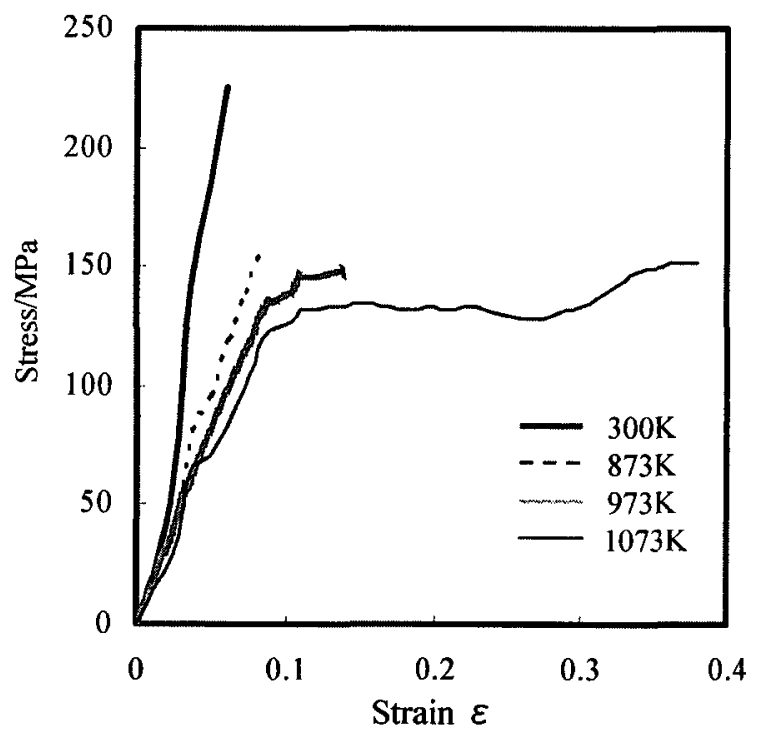

Fig.4 Stress-strain curves in compressive deformation at various temperatures for the alloy extruded at $910 \mathrm{~K}$. 


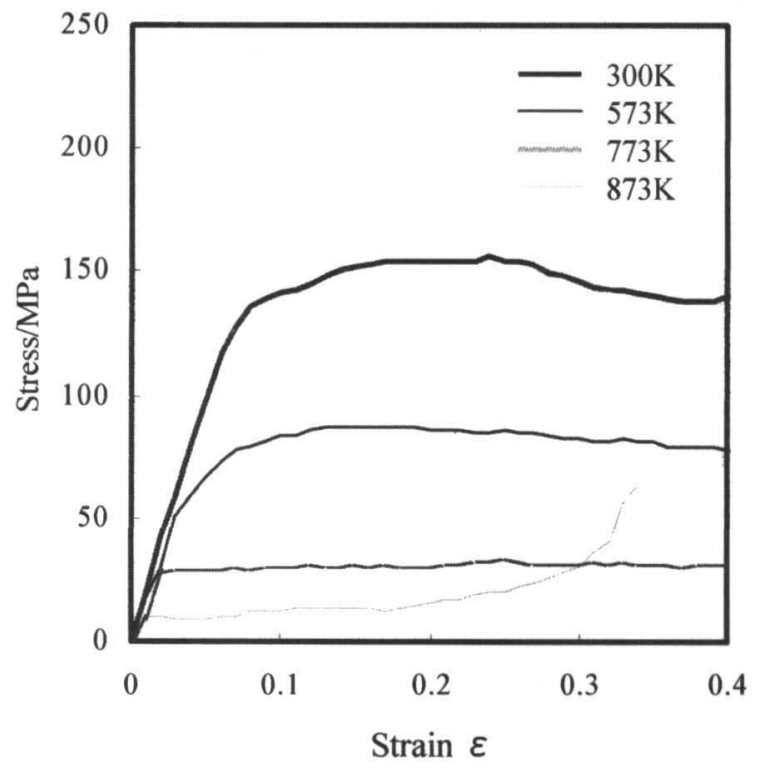

Fig.5 Stress-strain curves in compressive deformation at various temperatures for the alloy extruded at $1010 \mathrm{~K}$.

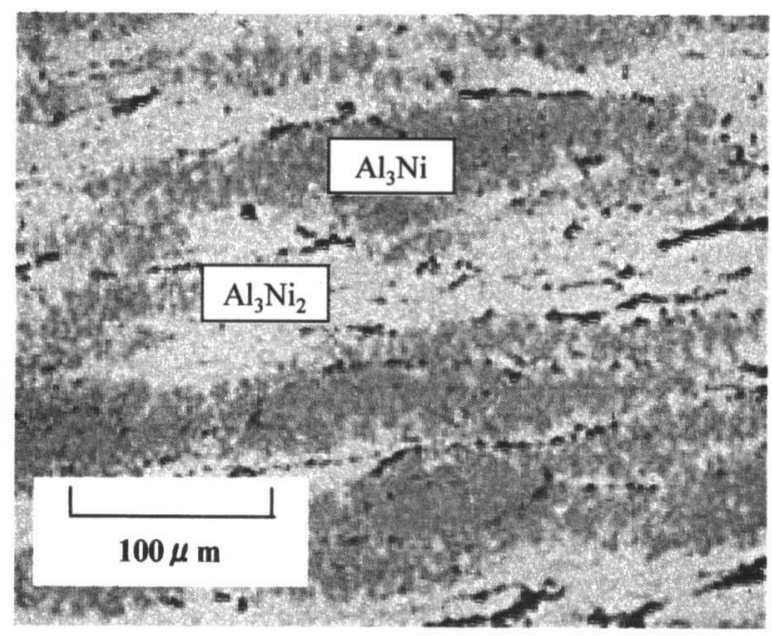

Fig.6 Optical micrograph of specimen compression-tested at 873 $\mathrm{K}$ for the alloy extruded at $1010 \mathrm{~K}$.

$873 \mathrm{~K}$ でひずみ0.3まで変形後の試験片について組織観察した. その結果をFig.6に示す.共晶組織はほとんど存在せず, $\mathrm{Al}_{3} \mathrm{Ni}_{2}$ 相と微細な $\mathrm{Al}_{3} \mathrm{Ni}$ 相であり，その体積率は $\mathrm{Al}_{3} \mathrm{Ni}_{2}$ 相が $28 \%$ で $\mathrm{Al}_{3} \mathrm{Ni}$ 相が72\%であるので，873 Kでの圧縮変形中に，共晶組 織は $\mathrm{Al}_{3} \mathrm{Ni}$ 相に変化することが確認された.これは共晶温度に 近い温度で変形すると, 焼なまし効果によって平衡相の $\mathrm{Al}_{3} \mathrm{Ni}$ 相に変化したものと考えられる.

\section{3 熱処理による組織制御と高温変形}

高温圧縮変形過程で共晶組織は消滅し, $\mathrm{Al}_{3} \mathrm{Ni}$ 相と $\mathrm{Al}_{3} \mathrm{Ni}_{2}$ 相 の存在量も変化した. そこで各成形体について共晶温度上下 の $873 \mathrm{~K}$ と $973 \mathrm{~K} て ゙ 3.6 \mathrm{ks}$ 保持, 空冷の熱処理を施し, 組織観 察し, 各相の体積率を調べるとともに, 高温圧縮試験を行っ た. Fig.7は $910 \mathrm{~K}$ 成形体について熱処理による各相の体積率

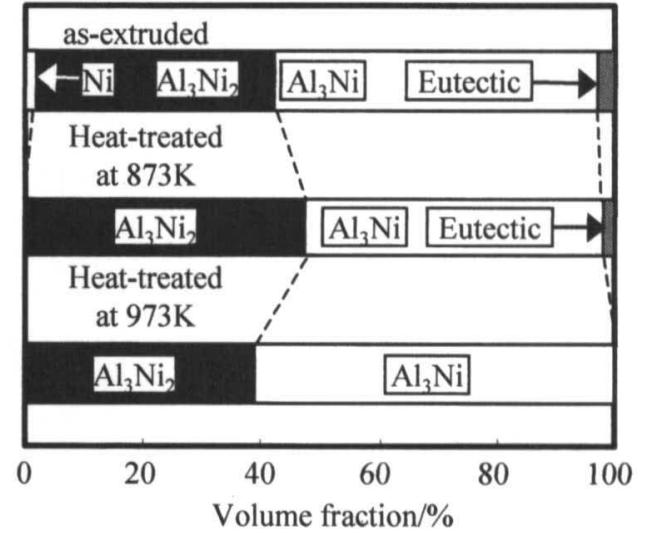

Fig.7 Influence of starting $\mathrm{Ni}$ particle size on volume fraction of each phase for alloys extruded at $910 \mathrm{~K}$ and $1010 \mathrm{~K}$.

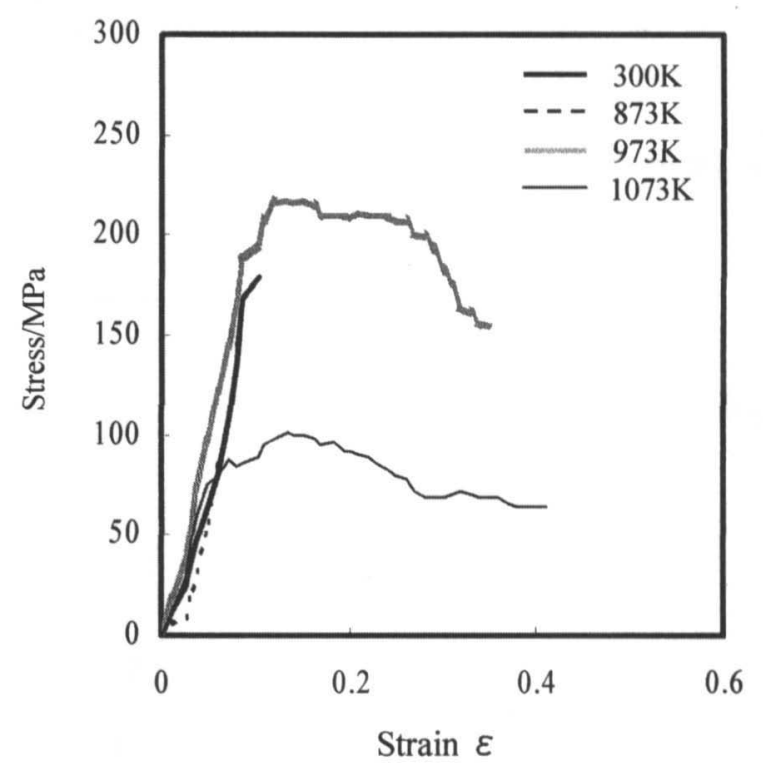

Fig.8 Stress-strain curves in compressive deformation at various temperatures for alloys heat-treated at $873 \mathrm{~K}$.

の変化を比較して示す. $873 \mathrm{~K}$ の熱処理で末反応の $\mathrm{Ni}$ は消滅 し, 高熱処理温度ほど共晶組織の量は減少した. また $\mathrm{Al}_{3} \mathrm{Ni}$ 相 と $\mathrm{Al}_{3} \mathrm{Ni}_{2}$ 相の体積率の割合は $\mathrm{Al}_{3} \mathrm{Ni}$ 相の方が増加し, 配合組成 の組織に近づいた。

$873 \mathrm{~K}$ と $973 \mathrm{~K}$ で熱処理した成形体について, 高温圧縮変形 における応力ーひずみ曲線をそれぞれ Fig.8 と Fig.9 に示す. $873 \mathrm{~K}$ 熱処理材ではFig.4に示した熱処理前の成形体と比較し, 降伏応力が上昇し, $973 \mathrm{~K}$ 以上の試験温度における延性も増加 する.配合組成は $\mathrm{Al}_{3} \mathrm{Ni}$ であるから, 高温変形ではさらに $\mathrm{Al}_{3} \mathrm{Ni}_{2}$ 相と共晶組織が $\mathrm{Al}_{3} \mathrm{Ni}$ 相へ組織変化しながら変形し, 延性が増 したものと思われる. $973 \mathrm{~K}$ 熱処理材では, 熱処理していない 押出し材と比較すると, 著しく降伏応力が増加し, 室温および $873 \mathrm{~K}$ の変形ではほとんど延性を示さない.そこで熱処理によ り組織制御した成形体の高温強度を比較するために, 圧縮降 伏応力について試験温度にともなう変化を Fig.10に示した. 


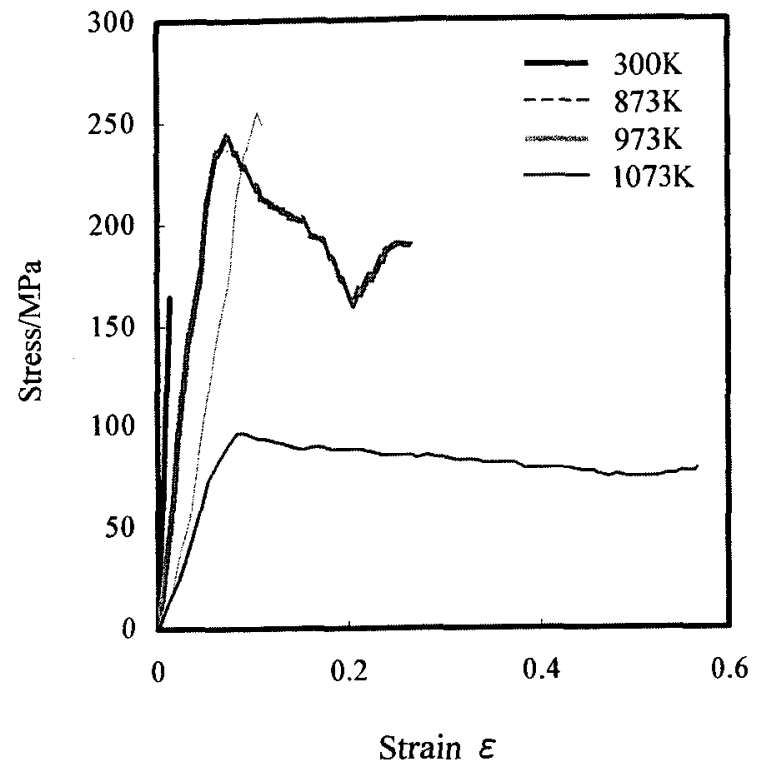

Fig.9 Stress-strain curves in compressive deformation at various temperatures for alloys heat-treated at $973 \mathrm{~K}$.

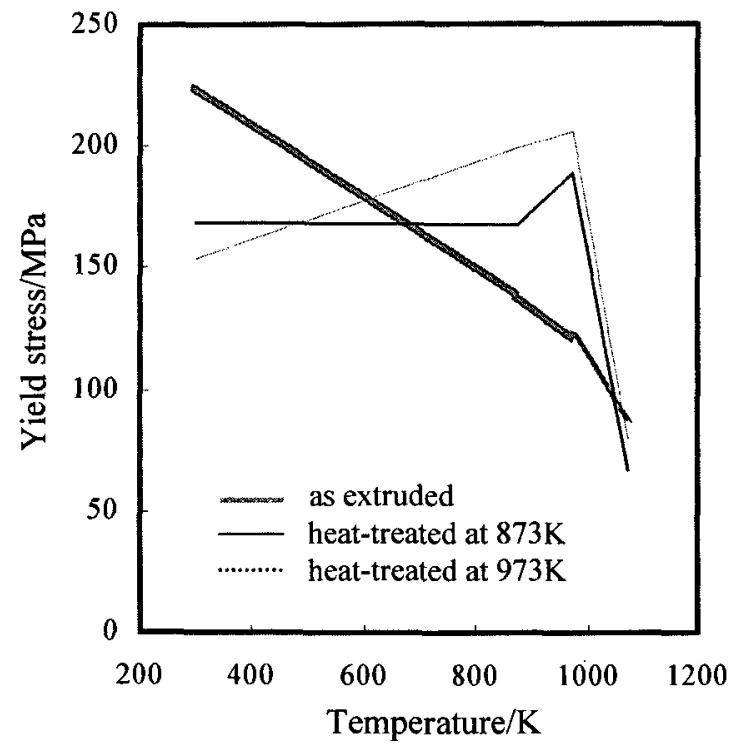

Fig.10 Relation between yield stress and temperature in the compressive test for as-extruded and heat-treated alloys.

押出しのままでは，末反応の $\mathrm{Ni}$ や共晶組織が存在するため， 試験温度か上昇するにしたがって降伏応力は低下する.しかし

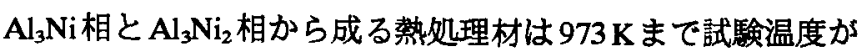
上昇するにしたがって降伏応力は增加する。一般に金属材料 は温度の上昇によって強度は低下するのが通例であるが，金 属間化合物では強度が上昇する逆温度依存性 ${ }^{10}$ を示す材料が ある. 本合金の $\mathrm{Al}_{3} \mathrm{Ni}_{\text {j }}$ よび $\mathrm{Al}_{3} \mathrm{Ni}_{2}$ 両金属間化合物も強度の逆 温度依存性を有していることが考えられる。そこで，各相の 圧縮降伏応力と試験温度の関係を評価するために,それそれの
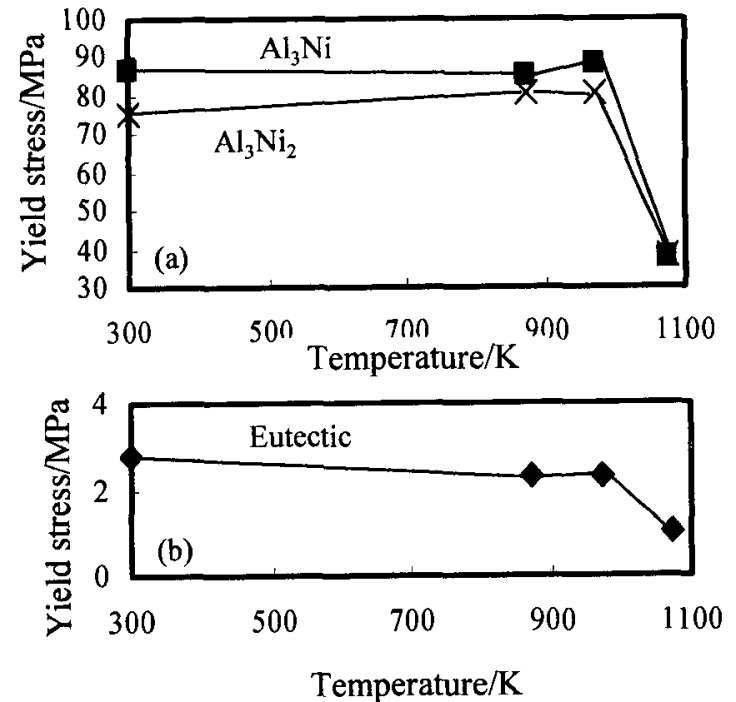

Fig.11 Relation between yield stress of each phase and temperature in the compressive test for $\mathrm{Al}-\mathrm{Ni}$ alloy.

成形体について，各相の体積率と圧縮降伏応力の間に複合則

$$
\sigma_{\mathrm{int}}=\sigma_{\mathrm{A}} \cdot \mathrm{V}_{\mathrm{A}}+\sigma_{\mathrm{B}} \cdot \mathrm{V}_{\mathrm{B}}+\sigma_{\mathrm{C}} \cdot \mathrm{V}_{\mathrm{C}}
$$

が成り立つと仮定し, 試験温度における各相の降伏応力を算 出した.ここで $\sigma_{\mathrm{int}}$ は合金の圧縮降伏応力で， $\sigma_{\mathrm{A}}, \sigma_{\mathrm{B}}, \sigma_{\mathrm{C}}$ と $\mathrm{V}_{\mathrm{A}}$, $\mathrm{V}_{\mathrm{B}}, \mathrm{V}_{\mathrm{C}}$ はそれそれ $\mathrm{Al}_{3} \mathrm{Ni}, \mathrm{Al}_{3} \mathrm{Ni}_{2}$, 共晶組織の圧縮降伏応力およ

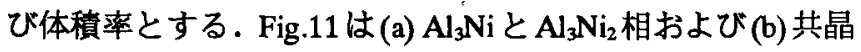
組織の試験温度にともなう圧縮降伏応力の変化を示す. $\mathrm{Al}_{3} \mathrm{Ni}$ と $\mathrm{Al}_{3} \mathrm{Ni}_{2}$ 両相とも $973 \mathrm{~K}$ まで試験温度の上昇にともない降伏応 力が高くなり，このような強度の逆温度依存性は $\mathrm{Al}_{3} \mathrm{Ni}_{2}$ 相の 方が顕著である. $\mathrm{Ni}_{3} \mathrm{Al}$ のような $\mathrm{L1}_{2}$ 型構造の金属間化合物の すべり変形は，超格子転位が部分転位に分解して運動し， ジョグを形成する.変形温度の上昇はこのジョク形成を容易 にするため, 転位運動の障害物が增し, 異常強化挙動 ${ }^{10,11)}$ 示す. $\mathrm{Al}_{3} \mathrm{Ni}$ は $\mathrm{DO}_{11}$ で $\mathrm{Al}_{3} \mathrm{Ni}_{2}$ は $\mathrm{D}_{13}$ 型構造をもち， $\mathrm{L1}_{2}$ 型構造 とはすべり系が異なるため, $\mathrm{L1}_{2}$ 型構造のような逆位相境界が 形成するか，あるいはTiAl系金属間化合物のように二相間の 結晶塑性異方性 ${ }^{11)}$ によるものか不明であり，今後さらに詳細 な研究が必要である。

\section{4 結言}

半溶融加工法を用いてAl-Ni金属間化合物を製造するために， $\mathrm{Al}-44$ mass\% $\mathrm{Ni}$ 混合粉末を $\mathrm{Al}$ 融点以下 $(910 \mathrm{~K})$ と以上 $(1010 \mathrm{~K})$ の温度で後方押出し加エして，生成相を調べた。その結果，

(1) $910 \mathrm{~K}$ 成形体は $\mathrm{Al}_{3} \mathrm{Ni}_{\text {と }} \mathrm{Al}_{3} \mathrm{Ni}_{2}$ 相加ら成り, 少量の共晶組 織と末反応 $\mathrm{Ni}$ 粒子が含まれる. 共晶組織と末反応 $\mathrm{Ni}$ 粒子 は配合する Ni 粉の粒径が大きいほど多くなる.

(2) $1010 \mathrm{~K}$ 成形体では $\mathrm{Al}_{3} \mathrm{Ni}$ 相と共晶組織から成り，配合する $\mathrm{Ni}$ 粉の粒径が大きいほど共晶組織は減少して, $\mathrm{Al}_{3} \mathrm{Ni}_{2}$ 相が 
生成する。

(3) 半溶融加エにより生成した各相の体積率は高温変形中ある いは熱処理によって変化し，末反応 $\mathrm{Ni}$ 粒子は消滅すると ともに，共晶組織は $\mathrm{Al}_{3} \mathrm{Ni}$ 相に変わる。 それそれの成形体および熱処理材を高温圧縮試験し,変形 挙動を調へた。るその結果，

(4) 共晶組織が含まれる成形体は高延性を示すが, $\mathrm{Al}_{3} \mathrm{Ni}$ お び $\mathrm{Al}_{3} \mathrm{Ni}_{2}$ 相の高体積率の合金は, 高温変形においても高い 圧縮降伏応力をもつ.

(5) $\mathrm{Al}_{3} \mathrm{Ni}$ および $\mathrm{Al}_{3} \mathrm{Ni}_{2}$ 相の圧縮降伏応力は, 変形温度が上昇 するほど高くなる強度の逆温度依存性をもつ可能性がある。 以上のように，混合粉末を出発材料として半溶融加工すれば， 溶製法より低温で金属間化合物が生成するとともに，その成 形が可能である。しかし，金属間化合物の強度特性は，成形 方法や加工度によって得られる組織，特に結晶粒径が異なる と考えられ，今後，これらの課題について検討したい.

\section{謝辞}

本研究を遂行するに当たり，実験にこ協力いただいた本学 機器分析センター吉田明講師, 新藤恵美技士および本学大学 院機械工学専攻山口康介君(現, 三菱重工業(侏))に感謝申し上 げます.また, 本研究の一部は文部科学省科学研究補助金よ り研究助成を受けたことを記しここに感謝の意を表します。

\section{文献}

1) D.Lawrynowicz, X.Liang, T.S.Srivatsan and E.J.Lavernia: "Processing, Microstructure and Fracture Behaviour of a Sprayatomized and Deposited Nickel Aluminide Intermetallic", J. Mater. Sci., 33(1998)1661-1675.

2) D.Bozic, N.Ilic, M.Mitkov and M.T.Jovanovic: "A Comparative Study of Microstructure, Mechanical and Fracture Properties of $\mathrm{Ni}_{3} \mathrm{Al}$-based Intermetallics Produced by Powder Metallurgy and
Standard Melting and Casting Processes", J. Mater. Sci., 31 (1996)3213-3221.

3) E.M.Schulson and D.R.Barker: "A Brittle to Ductile Transition in NiAl of a Critical Grain Size", Scripta Metall., 17(1983)519. 522.

4) H.Y.Sohn and X.Wang: "Mathematical and Experimental Investigation of the Self-Propagating High-temperature Synthesis (SHS) of $\mathrm{TiAl}_{3}$ and $\mathrm{Ni}_{3} \mathrm{Al}$ Intermetallic Compounds", J. Mater. Sci., 31(1996)3281-3288.

5) T.Cheng and M.McLean: "Characterization of TiAl Intermetallic Rods Produced from Elemental Powders by Hot Extrusion Reaction Synthesis (HERS)", J. Mater. Sci., 32(1997)62556261.

6) D.H.Kirkwood: "Semisolid Metal Processing", Inter. Mater. Reviews, 39(1994)173-189.

7) H.Nakato, M.Oka, S.Itoyama, M.Urata, T.Kawasaki, K.Hashiguchi and S.Okano: "Continuous Semi-Solid Casting Process for Aluminum Alloy Billets", Mater. Trans., 43(2002) 24-29.

8) 湯浅栄二, 山口康介, 近藤勝義, 相澤龍彦: "Al/Ni 混合粉 末の等速加熱にともなう金属間化合物の生成とその成形", 粉体および粉末治金, 49(2002)52-57.

9) K.Kondoh, H.Oginuma, E.Yuasa and T.Aizawa: "Solid-State Synthesis of $\mathrm{Mg}_{2} \mathrm{Si}$ from $\mathrm{Mg}-\mathrm{Si}$ Mixture Powder", Mater. Trans., 42(2001)1293-1300.

10) 日本材料科学会編: 金属間化合物と材料, 裳華房, (1995) 103.

11）馬越祐吉: " 金属間化合物の異常強化挙動 ", ふえらむ, 5 (2000)715-720.

12) H.W.Sizek and G.T.Gray: "Deformation of Polycrystalline $\mathrm{Ni}_{3} \mathrm{Al}$ at High Strain Rates and Elevated Temperatures", Acta Metall. Mater., 6(1993)1855-1860. 